\title{
708 火災時における原子力発電所用電気ケーブルの絶縁性および難燃性
}

Insulation properties and flame resistance of electrical cables for nuclear power plant in fire accidents

$$
\begin{aligned}
& \text { ○学 水田馨(筑波大) 正 松田昭博(筑波大) } \\
& \text { 石橋隆 (JNES) 土野進 (JNES) }
\end{aligned}
$$

Kaoru MIZUTA, Graduate student, University of Tsukuba, 1-1-1, Tennoudai, Tsukuba, Ibaraki

Akihiro MATSUDA, University of Tsukuba, 1-1-1, Tennoudai, Tsukuba, Ibaraki

Takashi ISHIBASHI, Japan Nuclear Energy Safety Organization, 3-17-1, Toranomon, Minato-ku, Tokyo

Susumu TSUCHINO, Japan Nuclear Energy Safety Organization, 3-17-1, Toranomon, Minato-ku, Tokyo

\begin{abstract}
The purpose of this study is to investigate insulation properties and flame resistance of electrical cables in fire. Insulation resistance of the cable is affected by the heat of a fire. Therefore, to ensure the safety of nuclear facilities in case of fire, it is necessary to clarify the combustion characteristics of electrical cables, construct damage prediction method.

In this paper, we conduct a combustion test on 3 type of electrical cable used in nuclear power plant.

From the test, we appraised insulation properties and combustion characteristics of each cable. Also shows a good correlation with insulation resistance and time by the Arrhenius plot.
\end{abstract}

Key Words: Electrical Cables, Nuclear Power Plant, Insulation Resistance

\section{1. 緒言}

原子力施設で火災事故が発生した場合，その施設内の制御 や動力供給を担う電気ケーブルの絶縁性や難燃性は適切に保 たれる必要がある。しかし，ケーブルの絶縁抵抗は，火災に よる熱によって影響を受ける。更に，温度が上昇し，ある温 度を越えた場合は, 電気ケーブル自体が燃焼し新たな火災源 となる可能性がある(1). そのため, 原子力施設の火災時の安 全性を確保するためには, 電気ケーブルの燃焼特性を明らか にし，その被害を予測できる評価方法を構築する必要がある.

そこで, 本研究は, 電気ケーブルの絶縁性や難燃性への熱 影響を予測できる方法の構築を目的とした．そのために，原 子力施設で使用されている電気ケーブルを対象とし, 火災を 想定した試験を実施した.

\section{2. 試験方法}

トレーに敷設されたケーブルに対して，コーンカロリーヒ ーターで放射熱を最長で 120 分間与えた。 その際の，ケーブ ルの温度, 絶縁抵抗, および絶縁抵抗が短絡する時間を計測 した.

図 1 の燃焼試験装置は，コーンカロリーヒーター試験装置 を改良して開発した試験装置であり,ケーブルトレーに敷設 したケーブルに対して試験を行うことができる.コーン型ヒ 一ターは、直径 $200 \mathrm{~mm}$ であり,ヒーター単体で室温から $800^{\circ} \mathrm{C}$ まで昇温可能である. 本試験では, ケーブル中心部表面の温 度をレーザー温度計で計測し, 試験条件と一致するようヒー ターを設定した。

絶縁抵抗の計測には，日置電機製の超絶縁計 SM-8215 を用 いた．計測する際の電圧は $500 \mathrm{~V}$ とした。

ケーブル試験片は，原子力発電所用動力・制御ケーブルで ある, SHCVV， FR-STP, CCSHVの 3 種類に対して試験を 行った. 同一ケーブル内の導線間の絶縁抵抗を計測した. 8 芯のケーブルは 4 芯を 1 束とし, 試験片の長さは $620 \mathrm{~mm}$ とし た.

図 2 にSHCVV の試験中の時間と絶縁抵抗の関係を示寸. ケーブル温度 $200^{\circ} \mathrm{C}$ の時には短絡せず，絶縁抵抗が 120 分保 たれた。しかし $220^{\circ} \mathrm{Cから} 460^{\circ} \mathrm{C}$ 条件では、発火はしないも のの, 温度の高いものから順にいずれも 120 分以内に短絡し

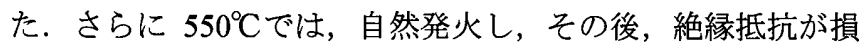
失した。同様に, FR-STP の時間と絶縁抵抗の関係を図 3 に, CCSHV の時閒と絶縁抵抗の関係を図 4 に示す.すべてのケー

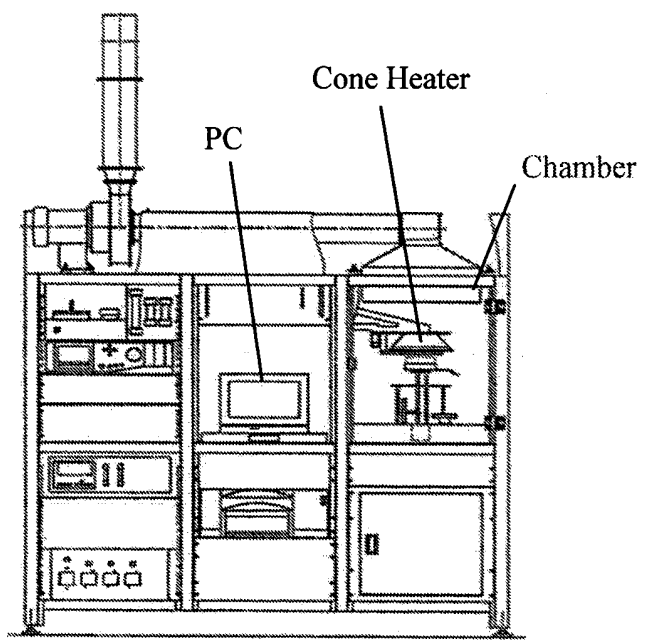

Fig. 1 Combustion Test Machine

ブルにおいて, 各温度の時間と絶縁抵抗の傾向は同一で, 120 分絶縁抵抗が保たれる温度があり，温度を上昇させることに よって徐々に短絡する時間が短くなった.ある温度になると， それ以上の温度では自然発火するようになり，発火後，絶縁 抵抗が損失した。

図 5 に各ケーブルの短絡時間とケーブル温度の関係の結果 を示す．横軸の短絡時間を対数表示としている。ここで，短 絡時間とは，加熱開始から短絡するまでの時間からヒーター 温度が目標の温度に達するまでの時間を引いたものである。 なお，時間と絶縁抵抗の関倸を以下の式で近似し，試験結果 に重ねて実線で示している.

$$
\theta_{S}=\theta_{\infty}+\left(\theta_{b}-\theta_{\infty}\right) \exp (-A t)
$$

ここで， $\theta_{s}$ は時刻 $\mathrm{t}$ においてケーブルが短絡する温度を， $\theta_{\text {。 }}$ 䋓縁抵抗が損失しない温度を， $\theta_{b}$ はケーブルが自然発 火する温度, もしくは即座に短絡する温度を，A は材料定数 を表す，近似曲線よりも下の領域では短絡することがなく， 上の領域では，短絡，もしくは発火の可能性があることを示 している.

図 6 に SHCVV の各抵抗值に達するまでの時間と温度の関 係をアレニウスプロット(2)にて示す.綐軸に, $10 \mathrm{M} \Omega, 20 \mathrm{M} \Omega$, 短絡するまでの時間 $T_{R}$ を対数でとり, 横軸に, ケーブル温度 (K)の逆数をとっている.アレニウスプロットの近似直線の傾 
きがどの結果においてもほぼ一致しており，ケーブルの絶縁 特性が，アレニウスプロットによって整理可能であることが わかった。 また，図より，以下の式が成り立つ。

$$
t=\exp \left(\frac{a}{\theta}\right)
$$

ここで， $a$ はアレニウスプロットにおける，近似直線の傾 きである. 図 6 において, それぞれの直線の傾きから, 各温 度における短絡時間, 各抵抗值に達する時間を求めることが できる。

図 7 に各ケーブルの安全温度と発火温度を示す. 絶縁抵抗 が損失しない温度を安全温度 $\theta_{\infty}$, ケーブルが自然発火する温 度を発火温度 $\theta_{b}$ としている.

\section{4. 結言}

本研究では, 原子力発電所で仕様されるケーブル 3 種類を 対象とした然焼実験を行った. 各ケーブルの絶縁性, 難燃性 を評価し, 安全温度, 発火温度を取得した. また, アレニウ スプロットを用いることにより，絶縁抵抗と時間に関して， 良好な相関を得た。

\section{参考文献}

（1）森孝太，松田昭博，火災力学シミュレータを用いた核燃 料加工施設内電気ケーブルの火災時安全性評価, 2011

(2) Edward L. King, HOW CHEMICAL REACTIONS OCCUR, 1963

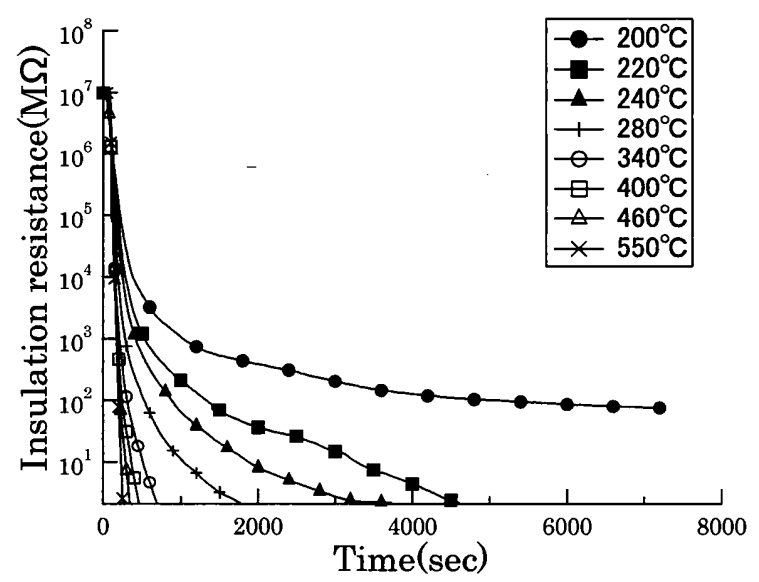

Fig.2 Insulation Resistance of SHCVV

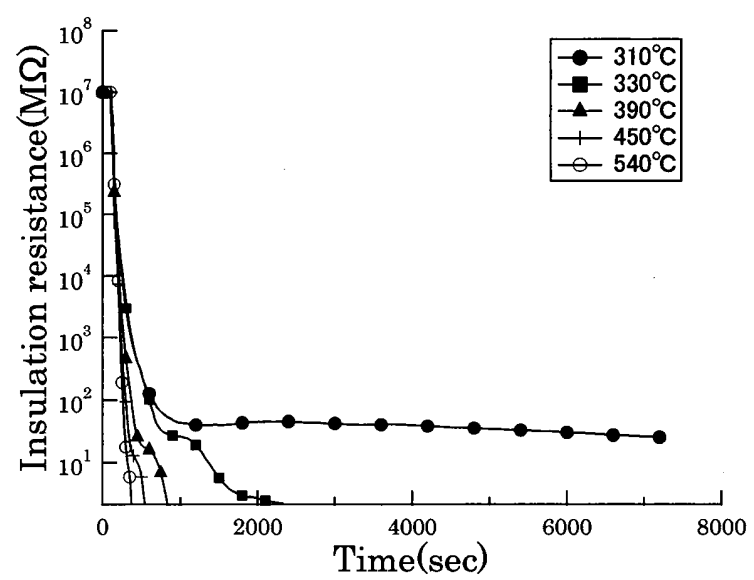

Fig.3 Insulation Resistance of FR-STP

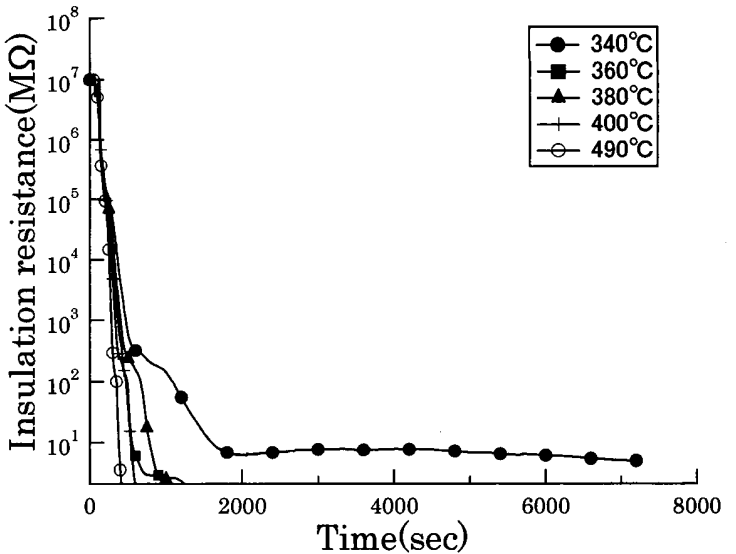

Fig.4 Insulation Resistance of CCSHV

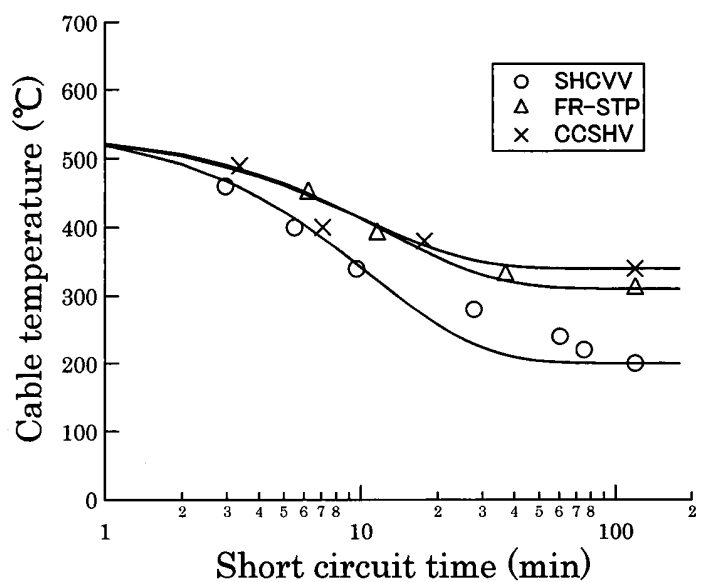

Fig.5 Approximation of Short Circuit Time

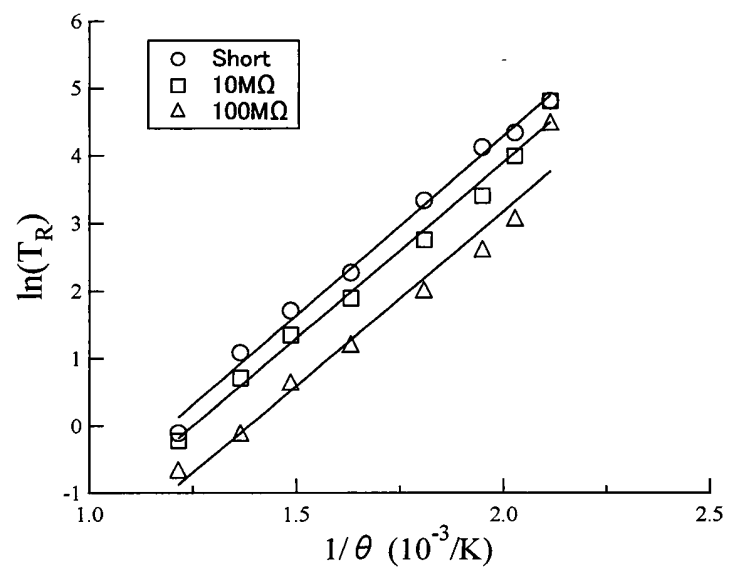

Fig.6 Arrhenius Plot Regarding $T_{R}$

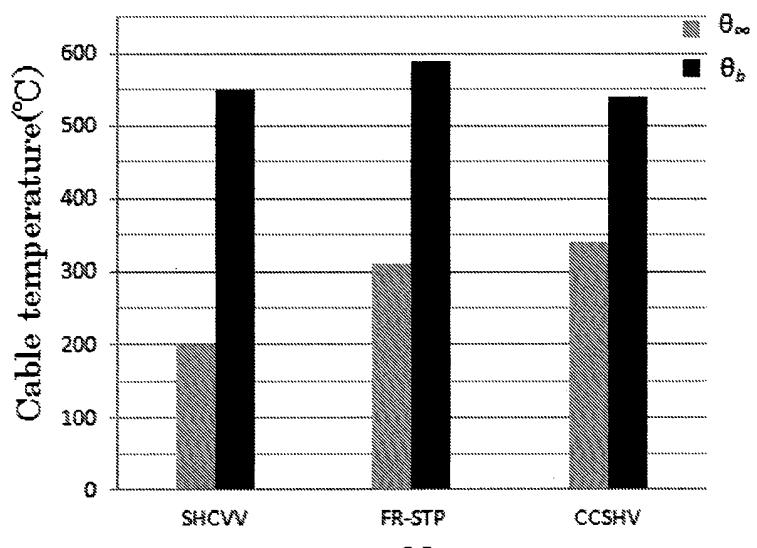

Cable

Fig.7 Temperature $\theta_{b}, \theta_{\infty}$ of Electrical Cables 